\title{
Effects of Crop Rotation and N-P Fertilizer Rate on Grain Yield and Related Characteristics of Maize and Soil Fertility at Bako, Western Oromia, Ethiopia
}

\author{
Tolera Abera $^{1 *}$, Daba Feyisa ${ }^{1}$, and D. K. Friesen ${ }^{2}$ \\ ${ }^{1}$ Oromia Agricultural Research Institute (OARI), Bako Agricultural Research Center, P O Box 26, Bako, Western \\ Oromia, Ethiopia \\ ${ }^{2}$ CIMMYT/IFDC, Regional Coordinator, P O Box 5689 Addis Ababa, Ethiopia
}

\begin{abstract}
A trial was conducted to determine the effects of crop rotation with N-P rates on grain yield of maize and soil fertility in Bako over a period of five years. The experiment was laid out in a randomized complete block design in factorial arrangement with rotation crops (Niger seed, haricot bean and tef) as main factor and two levels of NP fertilizers ( half recommended $\left(55 / 23 \mathrm{~kg} \mathrm{~N}-\mathrm{P}_{2} \mathrm{O}_{5} \mathrm{ha}^{-1}\right.$ and recommended $\left(110 / 46 \mathrm{~kg} \mathrm{~N}-\mathrm{P}_{2} \mathrm{O}_{5} \mathrm{ha}^{-1}\right)$ rate as sub factor and continuous maize with three replications. Higher mean grain yield of maize was recorded from maize following rotation crops with recommended rate of fertilizer compared to continuous maize. Maize following rotation crops gave mean grain yield advantage of 640 to 830 and 1921 to $1968 \mathrm{~kg} \mathrm{ha}^{-1}$ compared to continuous maize at half and full recommended N-P fertilizer rate. Maize following Niger seed produced mean grain yield advantage of 971 and $1527 \mathrm{~kg} \mathrm{ha}^{-1}$ compared to haricot bean and tef. Primary nutrient (N, P and K) composition of the tissue and grain of maize were significantly higher with maize following rotation crop compared to continuous maize, indicting the enhancement of the nutrient use efficiency of maize following rotation crops. Crop rotation with fertilizer amendment improved the $\mathrm{pH}$ of the soil. Crop rotation and N-P amendment enabled maize yields and soil fertility to be maintained at a higher level. Multiple advantages accrue from the use of crop rotation. Higher grain yield and high net return of maize were realized following Niger seed, haricot bean and tef compared to continuous maize. Maize following Niger seed followed by haricot bean with the recommended rate of fertilizer is a better management option for sustainable maize production in Western Oromia.
\end{abstract}

Keywords: Crop Rotation; Niger Seed; N-P Rate

\section{Introduction}

Soil degradation is occurring at an alarming rate and threatens soil productivity and maize production in Western Oromiya due to continuous cropping over the last three decades. Conventional agriculture (continuous cropping with inputs) has certain limitations in terms of maintaining long-term soil fertility (Charpentier et al., 1999). Longer cultivation has further depleted the soil organic-matter content and fertility (Wu et al., 2003). Crop rotation is the most among factors significantly increasing soil organic matters (Campbell et al., 1996). Legume-cereal and Oilseed-cereal sequence is the predominant cropping pattern practice by smallholder farmers in western Ethiopia (Asfaw et al., 1997). Crop rotation is necessary and the desirable management option to restore, maintain, enhance soil fertility, and maximize yield. Appropriate cropping sequence with continuous use of chemical fertilizers can increase the yield of annual crops in Alfisols (Henao and Bannante, 1999), which may be true for maize at Bako. Singh et al. (1987) reported that maize-wheat cropping systems with chemical fertilizers increased the grain yield of maize by $202 \%$ and of wheat by $176 \%$ compared to non-fertilized controls. The highest maize yield of $4550 \mathrm{~kg} / \mathrm{ha}$ was obtained from the annual crop rotation of berseem (Trifolium alexandrinum) maize followed by grain legume-maize sequence (3810 to $3870 \mathrm{~kg} / \mathrm{ha}$ ) (Ramteke et al., 1986). Rotations with legumes built up the $\mathrm{N}$ status of the soil. According to Zentner et al. (2001) N-requirement of wheat in continuous wheat or wheat-lentil rotation varied from 5 to $60 \mathrm{~kg} \mathrm{ha}{ }^{-1}$. The available soil $\mathrm{N}$ was increased by about 32 and $40 \mathrm{~kg} / \mathrm{ha}$ following chickpea and lentil compared to the preceding wheat (Patwary et al., 1989). Alvey et al. (2001), in their work, suggested that a wide spread use of cereal/legume rotations has been proposed as a means of sustainability to meet increasing food demands. Nugusse (1995) found that Haricot bean is the best precursor crop for maize at Awassa and Nazareth. Rao and Mathuva (2000) found that maize following annual legumes were 32 - $49 \%$ more profitable than continuous maize. However, Tadesse and Tolessa (1998) reported that Niger seed is the best precursor crop for maize with a yield advantage of $50 \%$ compared to sole cropping followed by haricot bean. Including oilseed crops in rotation with wheat may also increase soil productivity because of their deep root system to scavenge nutrients from lower root depths. It also produces root channels which may facilitate root development in subsequent cereal crop (Angus et al., 1991).

Maintenance of the soil fertility at the economic optimum level with appropriate crop rotation and affordable fertilizer rate is essential for sustainable maize production in the region. Identification of suitable crop rotation with optimum fertilizer was more reliable and generally maximized maize grain yield. Therefore, the objective of this study was to determine the appropriate crop rotation with optimum N-P rate for maize production.

\section{Materials and Methods}

A Crop rotation experiment was conducted during the 1999 to 2003 cropping seasons at Bako Agricultural Research Center (BARC), situated in Western Oromia, Ethiopia. The center is located in East Wollega Zone of the Oromia National Regional State. Geographically, it is

*Corresponding author. E-mail: thawwii@yahoo.com 
located between $9^{\circ} 6^{\prime} \mathrm{N}$ latitude and $37^{\circ} 09^{\prime} \mathrm{E}$ longitude. It has an aerial coverage of about 38 square kilometres; with a mean altitude of 1650 meters above sea level. The longterm (1961 - 2003) mean annual rainfall at BARC is 1239 $\mathrm{mm}$ with unimodal distribution. It has a warm humid climate with mean minimum, mean maximum and average air temperatures of $13.2,28$ and $21^{\circ} \mathrm{C}$, respectively (NMSA, 2003). Sixty percent of the soil (1400 ha) at Bako Research Center, is reddish brown in colour, clay and loam in texture (Wakene, 2001).

Agro-ecologically, BARC is classified as tepid to cool sub humid mid highlands and is a mixed farming zone, encompassed by Gibe River and with abundant natural vegetation, and grasslands. The major annual and perennial crops of the area include maize (Zea mays L.), sorghum (Sorghum bicolor L. Monch), teff (Eragrostis tef (Zucc.) Trotter), noug (Guizotia abyssinica), hot pepper (Capsicum frutescence L.), haricot bean (Phaseolus vulgars L.), sweet potato (Ipomoea batatas Lam.), mango (Mangifera indica L.), banana (Mussa spp), and sugar cane (Saccharum officinarum L.) in order of importance (Asfaw et al., 1997). During the 1999 cropping season, the trial area was sown to maize with recommended fertilizer $(110 / 46 \mathrm{~kg} \mathrm{~N} /$ $\left.\mathrm{P}_{2} \mathrm{O}_{5} \mathrm{ha}^{-1}\right)$ in order to make the field uniform. First, in the 2000 cropping season, rotation crops sown were local Niger seed (Guizotia abyssinica) and tef (Eragrostis Tef (Zucc.) Trotter), and Roba-1 of haricot bean (Phaseolus vulgars L.) varieties as well as continuous maize. During the 2001 cropping season, maize hybrid (BH-660) was sown with two levels of fertilizers, half recommended $\left(55 / 23 \mathrm{~kg} \mathrm{~N}-\mathrm{P}_{2} \mathrm{O}_{5} \mathrm{ha}^{-1}\right.$ and recommended $(110 / 46 \mathrm{~kg} \mathrm{~N}-$ $\left.\mathrm{P}_{2} \mathrm{O}_{5} \mathrm{ha}^{-1}\right)$ rate for the area.

In addition, during the 2002 cropping season, rotation crops (Niger seed, haricot bean and tef) and continuous maize were sown. During the 2003 cropping season, again maize hybrid (BH-660) was sown with two levels of fertilizers, half recommended $\left(55 / 23 \mathrm{~kg} \mathrm{~N}-\mathrm{P}_{2} \mathrm{O}_{5} \mathrm{ha}^{-1}\right.$ and recommended $\left(110 / 46 \mathrm{~kg} \mathrm{~N}-\mathrm{P}_{2} \mathrm{O}_{5} \mathrm{ha}^{-1}\right)$ rate for the area. The rotation system was one phase rotation cycle. The main factors were tef (Eragrostis Tef (Zucc.) Trotter), Niger seed (Guizotia abyssinica), and Haricot bean (Phaseolus vulgars L.) and control maize (Zea mays L.) with recommended fertilizer rate. The seed rates used were 25 $\mathrm{kg} \mathrm{ha}^{-1}$ for tef, $8 \mathrm{~kg} \mathrm{ha}^{-1}$ for Niger seed and $75 \mathrm{~kg} \mathrm{ha}^{-1}$ for Haricot bean.

The experiment was laid out in a randomized complete block design in factorial arrangement with rotation crops as main factor and N-P rate as sub-factors. The total gross plot size was $5.1 \times 4.5 \mathrm{~m}$ with $3 \times 5.1 \mathrm{~m}$ net plots. The spacing was $75 \times 30 \mathrm{~cm}$. The seed rate used for maize was $25 \mathrm{~kg} \mathrm{ha}^{-1}$. Sowing dates followed recommended date of planting ranged May 1 - 30. Full dose of phosphorus (as DAP) was applied once at planting, while nitrogen (as Urea) was applied in split doses, half at planting and the remaining half applied 30 to 40 days after planting. The maize grain yield was adjusted at $12.5 \%$ moisture level and given in $\mathrm{kg} \mathrm{ha}{ }^{-1}$. The data were analysed using MSTAT-C statistical packages (Freed et al., 1989).

The soil sample was collected at the depth $0-20 \mathrm{~cm}$ with augur three times, first before application of the treatment (1999), second after harvesting of the rotational crops in 2000 and when the field was ready for maize planting; third after harvesting of the main crop maize in 2003. Determination of soil particle size distribution was carried out using the hydrometer method (Dewis and Freitas, 1984). Soil $\mathrm{pH}$ was measured using digital $\mathrm{pH}$ meter in 1:2.5 soil to solution ratio with $\mathrm{H}_{2} \mathrm{O}$. Exchangeable basis were extracted with 1.0 Molar ammonium acetate at $\mathrm{pH}$ 7. $\mathrm{Ca}$ and $\mathrm{Mg}$ in the extract were measured by atomic absorption spectrophotometer while $\mathrm{Na}$ and $\mathrm{K}$ were determined using flame photometry (Van Reeuwijk, 1992). Cation exchange capacity of the soil was determined following the modified Kjeldahl procedure (Chapman, 1965) and reported as CEC of the soil. Percent base saturation was calculated from the sum of exchangeable basis as a percent of the CEC of the soil. Exchangeable acidity was determined by extracting the soil samples with M KCL solution and titrating with sodium hydroxide as described by McLean (1965). Organic carbon was determined following wet digestion methods as described by Walkley and Black (1934) whereas kjeldahl procedure was used for the determination of total $\mathrm{N}$ as described by Jackson (1958). The available $\mathrm{P}$ was measured by Olsen method as described by Olsen et al. (1954) and Bray II method (Bray and Kurtz, 1945). The electrical conductivity was estimated from saturated extracts of soil samples.

Plant tissues (leaves, stalk and grain) in 2001 and (leaves and stalk) in 2002 were collected during harvesting of maize crop. The plant tissue collected was analyzed in National Soil Research Center laboratory using standard procedures for different selected nutrient compositions.

For partial budget and marginal rate of return analysis, maize grain yield was valued at an average open market price of EB 265 per $100 \mathrm{~kg}$ for the last 10 years and maize seed price was EB 500 per $100 \mathrm{~kg}$. Labour cost for field operation was EB 7 per man-day. The yield was adjusted down by $10 \%$ to reflect actual production conditions (CIMMYT, 1988). The cost of fertilizers (Urea and DAP) amounted to EB 606 and 857 per $100 \mathrm{~kg}$ at the current market price.

\section{Result and Discussion \\ 3.1. Cropping Season}

The results of maize grain yield in 1999 and continuous maize and rotational crops in 2000 and 2002 cropping season are shown in (Table 1). The grain yields of different crops indicated the variation of yield across cropping seasons. Combined yields across years averaged $5615 \mathrm{~kg} \mathrm{ha}^{-1}$, but 6641 and $4579 \mathrm{~kg} \mathrm{ha}^{-1}$ in 2001 and 2003 cropping seasons (Table 3). Mean plant height over years averaged $267 \mathrm{~cm}$, but 290 and $244 \mathrm{~cm}$ in 2001 and 2003 cropping seasons (Table 3 ). Higher mean plant height and grain yield were found in 2001 cropping season. This might be due to the prevailing environmental conditions (sunshine, rainfall and temperature) during the growing seasons (Table 3). Year significantly $(p<0.05)$ affected mean plant height and grain yield of maize but nonsignificantly affected 1000 seed weight (Table 2 and 3). This might be due to the variation in climatic factors 
during the growing period of maize. Year by cropping rotation interaction significantly $(p<0.05)$ affected plant height and grain yield of maize indicating that the performance of rotational crops affects their residual effects and their contribution to soil fertility and grain yield of maize. Thus, cropping sequence consideration during crop rotation plays a significant role in the enhancement of soil fertility and grain yield of maize. In
2001 cropping season, higher mean plant height and grain yield of maize was recorded following haricot bean compared to Niger seed and tef. However, higher 1000 seed weight of maize was recorded following Niger seed and tef crops, respectively. Higher mean plant height, 1000 seed weight and grain yield maize were recorded following Niger seed compared to haricot bean and tef in 2003 and combined over years (Table 4).

Table 1. Mean grain yield of maize in 1999 and rotational crops (2000 and 2002) and continuous maize from 2000 to 2002.

\begin{tabular}{|c|c|c|c|c|}
\hline Maize $\left(\mathrm{kg} \mathrm{ha}^{-1}\right)$ & & Yield $\left(\mathrm{kg} \mathrm{ha}^{-1}\right)$ & & \\
\hline 1999 & Rotation crops & 2000 & 2001 & 2002 \\
\hline 4870 & Niger seed & 742 & & 734 \\
\hline 4708 & Niger seed & 749 & & 664 \\
\hline 6070 & Haricot bean & 1436 & & 1810 \\
\hline 5738 & Haricot bean & 1422 & & 1897 \\
\hline 4697 & Tef & 356 & & 396 \\
\hline 4515 & Tef & 392 & & 464 \\
\hline 5567 & Continuous maize & 8270 & 5544 & 2957 \\
\hline
\end{tabular}

\subsection{Plant Height}

Crop rotation significantly $(\mathrm{p}<0.05)$ affected mean plant height in 2003 and combined over years but had a nonsignificant ( $p>0.05)$ effect in 2001(Table 2 and 3). Mean plant height in 2003 and combined over years were significantly $(\mathrm{p}<0.05)$ affected by $\mathrm{N} / \mathrm{P}$ fertilizer rate (Tables 2 and 3). Plant height significantly increased with the rate of fertilizers. Recommended N-P rate gave higher plant height compared to half recommended in 2001, 2003 and combined over years (Table 3). The interactions of crop rotation and N-P fertilizer rate non-significantly ( $>>0.05$ ) affected mean plant height of maize (Table 2 and 3). Higher mean plant height of maize was observed from all three cropping sequences with recommended fertilizer compared to with half recommended (Table 3). This justifies the assertion that cropping sequence by itself does not boost the performance of maize without appropriate fertilizer rate.

\subsection{Thousand Seed Weight}

Cropping sequence and N-P rates non-significantly $(p>0.05)$ affected thousand seed weight (Table 2 and 3 ). The interactions of cropping sequence and N-P fertilizer rate non-significantly affected mean 1000 seed weight of maize (Table 2 and 3). Higher mean thousand seed weight of maize was recorded following cropping sequence with recommended fertilizer compared to half recommended (Table 3).

\subsection{Grain Yield}

Cropping sequence significantly $(\mathrm{p}<0.05)$ affected mean grain yield in 2003 and combined over years but had a non-significant effect in 2001 (Table 2 and 3). This revealed that cropping sequence had a significant effect on grain yield increment of maize. Maize following Niger seed produced 971 and $1255 \mathrm{~kg} \mathrm{ha} \mathrm{h}^{-1}$ higher combined grain yield advantage compared to following haricot bean and tef (Table 4). Mean grain yield was significantly $(\mathrm{p}<0.05)$ affected by N-P fertilizer rate (Table 2, 3 and 4$)$.
Grain yield significantly increased with the rate of fertilizers. Mean grain yield increased by 1281, 1138 and $1209 \mathrm{~kg} \mathrm{ha}^{-1}$ respectively as the rate of N-P increased from half recommended to recommended rate in 2001, 2003 and combined over years (Table 4). This justifies the claim that crop rotation with recommended dose of N-P fertilizers significantly increased grain yield of maize. Similarly, Shepherd and Sylvester-Bradley (1996) reported that the performance of succeeding crop was apparent when high, super-optimal fertilizer levels had been applied to preceding crops. Crop rotation by N-P fertilizer rate interaction non-significantly affected mean grain yield of maize (Table 2 and 3 ).

Maize following haricot bean produced higher mean grain yield at half recommended and recommended fertilizer compared to following Niger seed and tef in 2001 cropping season (Table 4). This might be due to the free nitrogen fixed by legumes in the soil which ameliorates the nitrogen status of the soil compared to oil crops and cereals. Conversely, maize following Niger seed in 2003 cropping season and combined over years gave a higher mean grain yield with half recommended fertilizer and recommended fertilizer compared to following haricot bean and tef (Table 3 and 4).

All crop rotations produced greater yield advantage of maize compared to continuous maize with recommended and half recommended fertilizer rates. At half the recommended fertilizer rate mean grain yield advantages of 640,830 and $735 \mathrm{~kg} \mathrm{ha}^{-1}$ were obtained following rotation crops compared to continuous maize in 2001, 2003 and combined across years (Table 3 and 4). However, at recommended fertilizer rate, maize following rotation crops gave mean grain yield advantage of 1921, 1968 and $1944 \mathrm{~kg} \mathrm{ha}^{-1}$ compared to continuous maize in 2001 and 2003 cropping season and combined over years (Table 3 and 4). In the same way, Higgs et al. (1990) reported 10 to $17 \%$ greater yield for corn grown in rotation with other crops compared to continuous cropping. A Similar result was reported by Halvorson et 
al. (2000); and Soper and Grenier (1987). Crop rotations with recommended fertilizer application produced better grain yield of maize. Similarly, Habtamu et al. (1996) found that crop rotation is more productive if it is supplemented with fertilizer application. The sustainable production of maize is possible by integrating crop rotation with recommended fertilizer levels. Sayre (1999) suggest that sustainable crop production practices involve the use of break crops and optimum fertilizer application which minimize nutrient losses. This could be due to the improvement in soil fertility status with different crops compared to continuous maize. The result agrees with (Reddy et al., 1994); and (Riedell et al., 1998). The higher yield of maize in crop rotation is due to the change in spatial and temporal difference of crops with time dimensions. In addition, variation in root structure and depth is one of the other benefits of crop rotation for change in soil fertility and can influence yield of crops by altering the physical and morphological properties of the soil. Higher mean grain yield increases of maize were achieved following Niger seed compared to haricot bean and tef with recommended and half recommended fertilizer rate. For sustainable production of maize, the use of different crop rotations with recommended and half recommended fertilizer rates are better than continuous planting of maize.

\subsection{Soil Chemical and Physical Properties}

The soil $\mathrm{pH}$ in $\mathrm{H}_{2} \mathrm{O}$ ranged from 5.0 to 5.5 and 3.7 to 4.9 in $\mathrm{KCl}$ in 2000 (Table 5). According to FAO, 1990 and Landon, 1991 such soils are acidic to strongly acidic. The soil $\mathrm{pH}$ in $\mathrm{H}_{2} \mathrm{O}$ ranged from 5.9 to 6.1 in 2003 (Table 6), indicating change in soil reaction from strongly acidic to moderately acidic. Crop rotation and N-P amendment significantly increased $\mathrm{pH}$ of the soil. Total $\mathrm{N}$ ranged from 0.13 to $0.17 \%$ in 2000 (Table 5) and 0.15 to $0.18 \%$ in 2003 (Table 6), which is categorized as low range according to FAO (1990). Soil from haricot bean field gave higher total $\mathrm{N}$ than from Niger seed and Tef crop fields (Table 5 and 6 ). This might be attributed to the nitrogen fixing nature of haricot bean. Similarly, Kumar et al. (1983); and Holford and Crocker (1997) reported legumes in crop rotation improve soil fertility, particularly soil $\mathrm{N}$ content. 
Table 2. Mean square for plant height, 1000 seed weight and grain yield ofr maize for each year and across two years at Bako.

\begin{tabular}{|c|c|c|c|c|c|c|c|c|c|c|}
\hline \multirow[t]{3}{*}{ Source of variation } & \multirow{3}{*}{ DF } & \multicolumn{9}{|c|}{ Mean square } \\
\hline & & \multicolumn{3}{|c|}{ Plant height $(\mathrm{cm})$} & \multicolumn{3}{|c|}{1000 seed weight $(\mathrm{g})$} & \multicolumn{3}{|c|}{ Grain yield (kg ha-1) } \\
\hline & & 2001 & 2003 & combined & 2001 & 2003 & combined & 2001 & 2003 & combined \\
\hline Year & 1 & & & $18815^{* *}$ & & & 355 & & & $37266465^{* *}$ \\
\hline Rotation crops (A) & 2 & 2510 & $620.20 * *$ & $1380 * *$ & 1231 & 5317 & 3753 & 2030640 & $9293369 * *$ & $5199292 * *$ \\
\hline N-P fertilizer rate (B) & 1 & 1300 & $4050 * *$ & $4970 * *$ & 20.06 & 5760 & 2550 & $7385041 * *$ & $5828836^{* *}$ & $13167898 * *$ \\
\hline $\mathrm{Ax} B$ & 2 & 1524 & 1.167 & 799 & 184 & 2061 & 988 & 396311 & 80474 & 309123 \\
\hline Year x A & 2 & & & 1749 & & & 2795 & & & $6124717 * *$ \\
\hline Year x B & 1 & & & 380 & & & 3230 & & & 45979 \\
\hline Year x A x B & 2 & & & 727 & & & 1257 & & & 167662 \\
\hline Error & $10(20)$ & 620.7 & 100.533 & 360.628 & 864.19 & 3108.6 & 1986 & 898233 & 148720 & 523476 \\
\hline $\mathrm{CV}(\%)$ & & 8.59 & 4.10 & 7.11 & 8.45 & 16.31 & 12.92 & 13.89 & 8.05 & 12.46 \\
\hline
\end{tabular}

(20) Combined degree of freedom for error, ** significant at $5 \%$ probability level

Table 3. Effects of rotation crops and N-P fertilizer rate on plant height, 1000 seed weight and grain yield of maize.

\begin{tabular}{|c|c|c|c|c|c|c|c|c|c|c|}
\hline \multirow{2}{*}{$\begin{array}{l}\text { Rotation } \\
\text { crops }\end{array}$} & \multirow[t]{2}{*}{ N-P fertilizer rate } & \multicolumn{3}{|c|}{ Plant height $(\mathrm{cm})$} & \multicolumn{3}{|c|}{1000 seed weight $(\mathrm{g})$} & \multicolumn{3}{|c|}{ Grain yield $\left(\mathrm{kg} \mathrm{ha}^{-1}\right)$} \\
\hline & & 2001 & 2003 & Mean & 2001 & 2003 & Mean & 2001 & 2003 & Mean \\
\hline Niger seed & Half recommended & 255 & 240 & 247 & 357 & 369 & 363 & 6228 & 5488 & 5858 \\
\hline Niger seed & Recommended & 301 & 270 & 285 & 365 & 366 & 365 & 7594 & 6884 & 7239 \\
\hline Haricot bean & Half recommended & 322 & 228 & 275 & 338 & 362 & 350 & 6484 & 3263 & 4874 \\
\hline Haricot bean & Recommended & 305 & 257 & 281 & 327 & 334 & 331 & 8231 & 4333 & 6282 \\
\hline Tef & Half recommended & 267 & 220 & 243 & 346 & 347 & 347 & 5839 & 3909 & 4874 \\
\hline Tef & Recommended & 290 & 250 & 270 & 355 & 271 & 313 & 6569 & 4858 & 5713 \\
\hline Continuous & Recommended & 322 & 251 & 273 & 327 & 374 & 350 & 5544 & 3390 & 4467 \\
\hline Mean & & 295 & 245 & 268 & 345 & 346 & 346 & 6641 & 4589 & 5615 \\
\hline \multirow[t]{3}{*}{$\operatorname{LSD}(5 \%)$} & Rotation crops & Ns & 12.90 & Ns & Ns & Ns & Ns & Ns & 496.1 & 930.7 \\
\hline & N-P rate & Ns & 10.53 & 13.20 & Ns & Ns & Ns & 995 & 405 & 503 \\
\hline & Rotation crops $\mathrm{x}$ N-P rate & Ns & Ns & Ns & Ns & Ns & Ns & Ns & $\mathrm{Ns}$ & Ns \\
\hline $\mathrm{CV}(\%)$ & & 8.59 & 4.10 & 7.11 & 8.45 & 16.31 & 12.92 & 13.89 & 8.05 & 12.46 \\
\hline
\end{tabular}

Recommended $=110 / 46 \mathrm{~kg} \mathrm{~N}-\mathrm{P}_{2} \mathrm{O}_{5} \mathrm{ha}^{-1}$, Half recommended $=55 / 23 \mathrm{~kg} \mathrm{~N}-\mathrm{P}_{2} \mathrm{O}_{5} \mathrm{ha}^{-1}, \mathrm{Ns}=$ non-significant

Table 4. Effects of rotation crops and N-P fertilizer rate on grain yield of maize.

\begin{tabular}{|c|c|c|c|c|c|c|c|}
\hline Treatment & 2001 & & 2003 & & Mean & & Rotation mean \\
\hline & Half recommended & Recommended & Half recommended & Recommended & Half recommended & Recommended & \\
\hline Niger seed & 6228 & 7594 & 5488 & 6884 & 5858 & 7239 & 6549 \\
\hline Haricot bean & 6484 & 8231 & 3263 & 4333 & 4874 & 6282 & 5578 \\
\hline Tef & 5839 & 6569 & 3909 & 4858 & 4874 & 5713 & 5294 \\
\hline Mean & 6184 & 7465 & 4220 & 5358 & 5202 & 6411 & \\
\hline $\begin{array}{l}\text { Rotation } \\
\text { crops }\end{array}$ & Ns & & 496.1 & & & & 930.7 \\
\hline $\mathrm{N}-\mathrm{P}$ rate & 995 & & 405 & & 503 & & \\
\hline $\mathrm{CV}(\%)$ & 13.89 & & 8.05 & & & 12.46 & \\
\hline
\end{tabular}


Tolera et al.

Campbell et al. (1992) reported accumulative enhancement of the $\mathrm{N}$-supplying power of the soil in wheat-lentil rotation. The increase in total $\mathrm{N}$ following haricot bean helps to reduce the amount of $\mathrm{N}$ required to optimize maize yield. Organic carbon contents of the soil ranged from 1.96 to $2.45 \%$ in 2000 and from 1.70 to 1.90 $\%$ in 2003 (Table 5 and 6) found in low range (FAO, 1990). This might be due to continuous cultivation of the field for the past three decades. Soil organic carbon contents declined regardless of inputs application for continuously cultivated land (Kapkiyai, 1996). Higher Organic carbon content next to before planting $(1.98 \%)$ was recorded from haricot bean field in 2000 and $(1.90$ $\%$ ) in 2003 from field treated with recommended fertilizer following Niger seed (Table 5 and 6). Higher C: $\mathrm{N}$ was recorded from Niger seed field in both years followed by haricot bean (Table 5 and 6). Available P in Olsen and Bray II method ranged from 6.4 to 21 and 5.6 to $36 \mathrm{ppm}$ and higher for preplant soil analysis compared to post harvest soil analysis result in 2000 (Table 5). In 2003, using Olsen procedure, available P ranged from
East African Journal of Sciences Volume 3 (1) $70-79$

5.12 to $7.86 \mathrm{ppm}$ (Table 6). This situation can be attributed to the high phosphorous fixing capacity of acid soil. The phosphorous content of the soil was found to be between moderate to adequate range for maize production (FAO, 1990). The exchangeable $\mathrm{K}, \mathrm{Ca}$, and $\mathrm{Mg}$ contents of the soil ranged from 0.21 to $0.41,1.10$ to 1.33 and 1.32 to 1.56 in 2000 and 1.24 to $2.55,4.19$ to 6.44 and 0.99 to $1.56 \mathrm{Meq} 100 \mathrm{~g}$ of soil ${ }^{-1}$ in 2003 (Table 5 and 6). The CEC of the soil ranged from 9.99 to 11.79 and 13 to $15 \mathrm{Meq} 100 \mathrm{~g}$ of soil-1 (Table 5 and 6) and location in the low range for maize production (FAO, 1990). The texture of the soil was sandy clay loam to clay (Table 5). Base saturation ranged from 24 to 34 and 41 to $78 \%$ (Table 5 and 6). The preplant soil analysis results were higher than post harvest soil analysis for different nutrients. The relatively low soil nutrient concentrations were due to continuous monocropping and cultivation over the last three decades which is consistent with Wakene et al. (2001).

Table 5. Result of soil chemical and physical analysis before sowing and after harvesting of break crops in 2000.

\begin{tabular}{lllllllllll}
\hline Treatment & $\mathrm{PH}$ & & T. N & O.C & C: N & \multicolumn{2}{l}{ Available P (ppm) } & K & Ca & Mg \\
\cline { 2 - 11 } & $\mathrm{H}_{2} \mathrm{O}$ & $\mathrm{KCl}$ & $(\%)$ & $(\%)$ & & Olsen & Bray II & Meq 100 g soil- ${ }^{-1}$ & \\
\hline Before sowing & 5.2 & 4.2 & 0.17 & 2.45 & 15 & 21.0 & 36 & 0.41 & 1.33 & 1.56 \\
Niger seed & 5.5 & 3.9 & 0.13 & 1.96 & 15 & 7.2 & 8.0 & 0.28 & 1.18 & 1.48 \\
Haricot bean & 5.0 & 3.7 & 0.15 & 1.98 & 13 & 7.6 & 9.0 & 0.24 & 1.10 & 1.40 \\
Tef & 5.0 & 3.8 & 0.14 & 1.90 & 14 & 6.8 & 9.0 & 0.21 & 1.13 & 1.32 \\
Continuous & 5.0 & 4.9 & 0.17 & 1.96 & 12 & 6.4 & 5.60 & 0.28 & 1.31 & 1.56 \\
\hline
\end{tabular}

T.N, total nitrogen; O.C, organic carbon; C.N, carbon nitrogen ratio

Table 5. Result of soil chemical and physical analysis before sowing and after harvesting of break crops in 2000...continued

\begin{tabular}{llllllll}
\hline \multirow{2}{*}{ Treatment } & \multicolumn{2}{l}{ Soil texture } & \multicolumn{7}{l}{ CEC Meq/100 } & Base Saturation & Exchange acidity \\
\cline { 2 - 5 } & Sandy $(\%)$ & Silt $(\%)$ & Clay $(\%)$ & Class & & & \\
\hline Before sowing & 44 & 14 & 42 & C & 9.99 & 34 & 0.29 \\
Niger seed & 38 & 14 & 48 & C & 9.99 & 31 & 0.78 \\
Haricot bean & 58 & 10 & 32 & SCL & 11.79 & 24 & 0.88 \\
Tef & 36 & 14 & 50 & C & 10.99 & 25 & 0.83 \\
Continuous & 38 & 14 & 48 & C & 11.59 & 28 & 0.53 \\
\hline
\end{tabular}

\subsection{Plant Tissue}

Nitrogen contents of the leaves were significantly higher in rotation compared to continuous maize in 2001 (Table 7). In 2003, $\mathrm{N}$ contents of the leaves were higher in maize following Niger seed and haricot bean with half recommended N-P rates compared to continues maize (Table 8). Nitrogen contents of the leaves ranged from 0.64 to $1.01 \%$ and 0.40 to $0.55 \%$, respectively in 2001 and 2003 (Tables 7 and 8). A Significant increase in N concentration in leaves occurred following crops compared to continuous cropping. An appreciably higher $(1.01 \%) \mathrm{N}$ concentration resulted from maize following haricot bean (Table 7), indicating higher carry over effect of $\mathrm{N}$ following haricot bean. This indicates high residual $\mathrm{N}$ following haricot bean was available for maize. Thus, use of crop rotation improved nutrient uptake efficiency of maize. Phosphorous concentration of the leaves of maize in rotation was higher, up to 240 and $140 \mathrm{ppm}$, in 2001 and 2003 than continuous maize except maize following tef in 2001 and maize after Niger seed in 2003 planted with half recommended fertilizer rate (Tables 7 and 8). The $K$ concentration of the leaves was higher in continuous maize, except maize following tef with half recommended fertilizer rate (Table 7). Stalk N concentration was inconsistent across two years (Tables 7 and 8). Higher N concentration 0.88 and $0.48 \%$ in 2001 and 2003 was recorded in maize following Niger seed and tef. P content of the stalk less or equivalent to continuous maize except maize following tef with recommended fertilizer rate in 2003 (Table 7 and 8). With the exception of maize following Niger seed and tef with recommended fertilizer rate, the other treatments had higher potassium in the stalk compared to continuous maize in 2001 (Table 7). 
Table 6. Result of soil chemical analysis after harvesting of maize crops in 2003.

\begin{tabular}{|c|c|c|c|c|c|c|c|c|c|c|c|c|}
\hline \multirow[t]{2}{*}{ Rotation crops } & \multirow[t]{2}{*}{$\mathrm{N}-\mathrm{P}$ rate } & \multirow{2}{*}{$\begin{array}{l}\mathrm{PH}: \\
\mathrm{H}_{2} \mathrm{O}\end{array}$} & \multirow{2}{*}{$\begin{array}{l}\text { T.N } \\
\%)\end{array}$} & \multirow{2}{*}{$\frac{\text { O.C }}{(\%)}$} & \multirow[t]{2}{*}{ C: $N$} & \multirow{2}{*}{$\begin{array}{l}\text { Available P } \\
\text { (ppm) }\end{array}$} & \multirow{2}{*}{\multicolumn{2}{|c|}{$\begin{array}{l}\text { K } \quad \text { Ca } \\
\text { Meq } 100 \text { g soil- }^{-1}\end{array}$}} & \multirow[t]{2}{*}{$\mathrm{Mg}$} & \multirow{2}{*}{$\begin{array}{l}\text { E.C } \\
\text { Ds } \mathrm{m}^{-1}\end{array}$} & \multirow{2}{*}{$\begin{array}{l}\text { CEC } \\
\text { Meq100-1 }\end{array}$} & \multirow{2}{*}{$\begin{array}{l}\text { Base Saturation } \\
\%\end{array}$} \\
\hline & & & & & & & & & & & & \\
\hline Niger seed & Half recommended & 5.9 & 0.15 & 1.70 & 11 & 5.60 & 1.62 & 5.89 & 1.40 & 0.06 & 14 & 67 \\
\hline Niger seed & Recommended & 5.9 & 0.15 & 1.90 & 13 & 6.48 & 1.56 & 5.14 & 1.32 & 0.07 & 15 & 55 \\
\hline Haricot bean & Half recommended & 6.0 & 0.15 & 1.82 & 12 & 7.50 & 1.58 & 5.59 & 1.24 & 0.08 & 15 & 59 \\
\hline Haricot bean & Recommended & 5.9 & 0.16 & 1.78 & 11 & 7.38 & 1.24 & 4.54 & 0.99 & 0.06 & 17 & 41 \\
\hline Tef & Half recommended & 6.0 & 0.16 & 1.72 & 11 & 7.38 & 1.24 & 4.49 & 1.15 & 0.07 & 16 & 44 \\
\hline Tef & Recommended & 5.9 & 0.15 & 1.70 & 11 & 7.86 & 1.59 & 4.19 & 1.07 & 0.06 & 15 & 47 \\
\hline Continuous & Recommended & 6.0 & 0.18 & 1.78 & 10 & 6.52 & 2.55 & 5.69 & 1.56 & 0.06 & 13 & 78 \\
\hline
\end{tabular}

Recommended $=110 / 46 \mathrm{~kg} \mathrm{~N}-\mathrm{P}_{2} \mathrm{O}_{5} \mathrm{ha}^{-1}$, Half recommended $=55 / 23 \mathrm{~kg} \mathrm{~N}-\mathrm{P}_{2} \mathrm{O}_{5} \mathrm{ha}^{-1}$

T.N, total nitrogen; O.C, organic carbon; C.N, carbon nitrogen ratio

Table 7. Maize tissue analysis (leave, stalk and grain) for primary nutrients in 2001.

\begin{tabular}{|c|c|c|c|c|c|c|c|c|c|c|}
\hline \multirow{3}{*}{$\begin{array}{l}\text { Rotation } \\
\text { crops }\end{array}$} & \multirow{3}{*}{ N-P fertilizer rate } & \multicolumn{9}{|c|}{ Maize tissue analysis } \\
\hline & & \multicolumn{3}{|c|}{ Leaves } & \multicolumn{3}{|l|}{ Stalk } & \multicolumn{3}{|l|}{ Grain } \\
\hline & & $\mathrm{N}(\%)$ & $\mathrm{P}(\mathrm{ppm})$ & $\mathrm{K}(\mathrm{ppm})$ & $\mathrm{N}(\%)$ & $\mathrm{P}(\mathrm{ppm})$ & $\mathrm{K}$ (ppm) & $\mathrm{N}(\%)$ & $\mathrm{P}$ (ppm) & $\mathrm{K}(\mathrm{ppm})$ \\
\hline Niger seed & Half recommended & 0.74 & 580 & 4900 & 0.88 & 150 & 18440 & 1.15 & 2390 & 4020 \\
\hline Niger seed & Recommended & 0.95 & 630 & 4700 & 0.23 & 80 & 14490 & 1.27 & 2720 & 4630 \\
\hline Haricot bean & Half recommended & 1.01 & 730 & 4890 & 0.30 & 130 & 17510 & 4.44 & 1880 & 3690 \\
\hline Haricot bean & Recommended & 0.74 & 600 & 4830 & 0.25 & 160 & 19770 & 3.63 & 1590 & 3240 \\
\hline Tef & Half recommended & 0.71 & 320 & 8040 & 0.46 & 120 & 17520 & 5.95 & 2200 & 4280 \\
\hline Tef & Recommended & 0.74 & 590 & 4840 & 0.44 & 220 & 16780 & 1.17 & 2980 & 5340 \\
\hline Continuous & Recommended & 0.64 & 490 & 5920 & 0.30 & 160 & 16940 & 1.00 & 2380 & 4260 \\
\hline
\end{tabular}

Recommended $=110 / 46 \mathrm{~kg} \mathrm{~N}-\mathrm{P}_{2} \mathrm{O}_{5} \mathrm{ha}^{-1}$, Half recommended $=55 / 23 \mathrm{~kg} \mathrm{~N}-\mathrm{P}_{2} \mathrm{O}_{5} \mathrm{ha}^{-1}$ 
Tolera et al.

Maize grain nitrogen concentrations significantly increased in rotation compared to continuous cropping (Table 7). Maize grain $\mathrm{N}$ concentration in rotation ranged from 0.142 to $4.94 \%$ (Table 7). Higher mean $\mathrm{N}$ grain concentration was recorded from maize following haricot bean followed by tef compared to Niger seed and continuous maize (Table 7). Application of higher $\mathrm{N}$ reduced $\mathrm{N}$ concentration in maize grain (Table 7 ). This might be due to the increase of $\mathrm{N}$ use efficiency of maize with higher application $\mathrm{N}$ fertilizer. Non-significant increase in maize grain $\mathrm{P}$ concentration occurred with maize following Niger seed with half recommended fertilizer but a significant increase was registered following Niger seed and tef with recommended fertilizer rate compared to continuous maize (Table 7). A Significant decrease in maize grain $\mathrm{P}$ concentration was achieved from maize following haricot bean with both fertilizers as compared to continuous maize (Table 7). Maize grain K concentration ranged from 1020 to 1080 (Table 7). With the except of maize following haricot bean, grain $\mathrm{P}$ and $\mathrm{K}$ concentration increased with additional increment of $\mathrm{P}$ application (Table 7). In general, the concentration of NPK in maize tissue and grain was higher with maize following break crops than continuous maize which agrees with the report of Copeland and Crookston (1992). Macronutrients (N.P
East African Journal of Sciences Volume 3 (1) $70-79$

and $\mathrm{K}$ ) accumulation in corn tissue at physiological maturity and grain yield were greater in rotation than corn grown in monoculture.

The results of economic analysis for N-P fertilizer rate and rotation crops are shown in (Tables 9 and 10). The highest net benefit of EB 13210 ha $^{-1}$ and marginal rate of return $177 \%$ came from the application of recommended $\left(110 / 46 \mathrm{~kg} \mathrm{~N}-\mathrm{P}_{2} \mathrm{O}_{5} \mathrm{ha}^{-1}\right)$ rate compared to the half recommended that was EB $11365 \mathrm{ha}^{-1}$ (Table 9). The values to cost ratio $\mathrm{EB} 10.92$ and 6.34 per unit of investment was for half recommended and recommended N-P fertilizer rate. The result for rotation crops indicted that the highest net benefit of EB 15619 ha $^{-1}$ of maize was obtained from maize following Niger seed (Table 10). The second net benefit of EB 13304 ha $^{-1}$ was achieved from maize following haricot bean (Table 10). The net economic returns of maize following Niger seed, haricot bean and tef were EB 4965, 2650 and 1972 ha $^{-1}$ respectively, higher than continuous maize (Table 10). This indicates that rotating maize with oil crops and legumes gave better cereals. It was found that yield and economic return from the rotation crops were significantly higher than from continuous cropping. Rotating maize improved to a greater extent than adding inputs to continuous maize.

Table 8. Maize tissue analysis (leave and stalk) for primary nutrients in 2003.

\begin{tabular}{|c|c|c|c|c|c|}
\hline \multirow{3}{*}{ Rotation crops } & \multirow{3}{*}{ N-P fertilizer rate } & \multicolumn{4}{|c|}{ Maize tissue analysis } \\
\hline & & \multicolumn{2}{|c|}{ Leaves } & \multicolumn{2}{|l|}{ Stalk } \\
\hline & & $\mathrm{N}(\%)$ & $\mathrm{P}(\mathrm{ppm})$ & $\mathrm{N}(\%)$ & $\mathrm{P}(\mathrm{ppm})$ \\
\hline Niger seed & Half recommended & 0.31 & 420 & 0.31 & 260 \\
\hline Niger seed & Recommended & 0.40 & 300 & 0.28 & 300 \\
\hline Haricot bean & Half recommended & 0.34 & 260 & 0.36 & 280 \\
\hline Haricot bean & Recommended & 0.55 & 380 & 0.28 & 160 \\
\hline Tef & Half recommended & 0.60 & 360 & 0.23 & 200 \\
\hline Tef & Recommended & 0.54 & 340 & 0.48 & 180 \\
\hline Continuous & Recommended & 0.44 & 200 & 0.32 & 300 \\
\hline
\end{tabular}

Recommended $=110 / 46 \mathrm{~kg} \mathrm{~N}-\mathrm{P}_{2} \mathrm{O}_{5} \mathrm{ha}^{-1}$, Half recommended $=55 / 23 \mathrm{~kg} \mathrm{~N}-\mathrm{P}_{2} \mathrm{O}_{5} \mathrm{ha}^{-1}$

Table 9. Partial budget and marginal rate of return analyses for N-P fertilizer rate on the mean grain yield of maize at Bako.

\begin{tabular}{|c|c|c|}
\hline \multirow[b]{2}{*}{ Items } & \multicolumn{2}{|c|}{$\mathrm{N}-\mathrm{P}_{2} \mathrm{O}_{5}$ fertilizer rate } \\
\hline & $100-50 \mathrm{~kg} \mathrm{ha}^{-1}$ & $200-100 \mathrm{~kg} \mathrm{ha}^{-1}$ \\
\hline Average yield $\left(\mathrm{kg} \mathrm{ha}^{-1}\right)$ maize & 5202 & 6412 \\
\hline Adjusted yield $\left(\mathrm{kg} \mathrm{ha}^{-1}\right)$ maize & 4681.8 & 5770.8 \\
\hline Gross field benefit of maize & 12407 & 15293 \\
\hline Costs Urea $\left(\mathrm{EB} \mathrm{ha}^{-1}\right)$ & 606 & 1212 \\
\hline Costs DAP $\left(\mathrm{EB} \mathrm{ha}^{-1}\right)$ & 428.5 & 857 \\
\hline Fertilizer application cost $\left(\mathrm{EB} \mathrm{ha}^{-1}\right)$ & 7.00 & 14.00 \\
\hline Total costs that vary $\left(\mathrm{EB} \mathrm{ha}^{-1}\right)$ & 1041.5 & 2083 \\
\hline Net benefit & 11365.5 & 13210 \\
\hline Values to cost ratio & 10.92 & 6.34 \\
\hline Marginal rate of return (MRR) & & $177 \%$ \\
\hline
\end{tabular}

Note: Grain price $=$ EB $2.65 \mathrm{~kg}^{-1}$, Seed price $=E B 5 \mathrm{~kg}^{-1}$, Labour cost $=$ EB $7.00 /$ day Yield was down adjusted with $10 \%$ coefficient, Cost of Urea $=E B 6.06 \mathrm{~kg}^{-1} \mathrm{DAP}=\mathrm{EB} 8.57 \mathrm{~kg}^{-1}$. 
Table 10. Partial budget and marginal rate of return analyses for rotation crops on the mean grain yield of maize at Bako.

\begin{tabular}{lllll}
\hline \multirow{2}{*}{ Items } & \multicolumn{2}{l}{ Rotation crops } & Continuous maize \\
\cline { 2 - 4 } & Niger seed & Haricot bean & Tef & \\
\hline Average yield $\left(\mathrm{kg} \mathrm{ha}^{-1}\right)$ maize & 6549 & 5578 & 5294 & 4467 \\
Adjusted yield $\left(\mathrm{kg} \mathrm{ha}^{-1}\right)$ maize & 5894.1 & 5020.2 & 4764.6 & 4020.3 \\
Gross field benefit of maize & 15619 & 13304 & 12626 & 10654 \\
Net benefit & 15619 & 13304 & 12626 & 10654 \\
\hline
\end{tabular}

Note: Grain price $=$ EB $2.65 \mathrm{~kg}^{-1}$, Seed price $=$ EB $5.00 \mathrm{~kg}^{-1}$, Labour cost $=$ EB $7.00 /$ day Yield was down adjusted with 10\% coefficient

\section{Conclusion}

Maize grain yields increased significantly following rotation crops compared to continuous cropping. Primary nutrient (N, P and $\mathrm{K}$ ) composition of the tissue and grain of maize increased following rotation crops. The maintenance and enhancement of soil fertility is possible through appropriate application of N-P rate and crop rotation. The use of crop rotation is the cheapest method of soil fertility replenishment for resource poor farmers. The result demonstrated the residual benefits of crop rotation with N-P fertilizer, enhancing the grain yields and fertility of the soil. Therefore, maize following Niger seed and haricot bean with recommended N-P fertilizer application is recommended for sustainable maize production in Bako area.

\section{Acknowledgement}

The authors thank CIMMYT and Oromiya Agricultural Research Institute (OARI) of the Oromiya National Regional State for funding the project. We are also grateful to Mr. Yosef kenea, Mr. Tesfaye G/girogis, Mr. Amsalu Fekadu, Mr. Hirko Sukari, Mr. Tesfa Borena and Mr. Bekele Wakijira for their unreserved efforts in managing the experiment and efficiently collecting the data. Special thanks to Addee Kisi Abichu for her patience and help during the research work.

\section{References}

Alvey, S., Bagayoko, M., Neumann, G. and Buerket, A. 2001. Cereal/legume rotations affect chemical properties and biological activities in two West African soil. Plant and Soil 101: 45 - 54.

Angus, J. F., vanHerWaaden, A. F. and Howe, G.N. 1991. Productivity and Beak Crop Effects of winter-Growing Oilseeds. Australian Journal of Experimental Agriculture 31: 669-677.

Asfaw, N., Abdissa G., Tesfaye K. and Gemechu, G. 1997. Agro ecological and socioeconomical circumstances of farmers in east Wellega zone of Oromiya region. Research report No. 32. Institute of Agriculture Research (IAR). Addis Ababa, Ethiopia. pp. 22 .

Bray, H.R. and Kurtz, L. 1945. Determination of organic and available forms of phosphorus in soils. Soil Science 9: 39-46.

Campbell, C.A., Zentner, R.P., Selles, F., Bierderbeck, V.O. and Leyshon, A.J. 1992. Comparative effects of grain lentil-wheat and monoculture wheat on crop production. $\mathrm{N}$ economy and $\mathrm{N}$ fertility in brown
Chernozem. Canadian Journal Plant Science 72: 10911107.

Campbell, C.A., McConkey, B.G., Zentner, R.P. Selles, F. and Curtin, D. 1996. Long-term effects of tillage and crop rotations on soil organic $\mathrm{C}$ and total $\mathrm{N}$ in a clay soil in South-western Saskatchewan. Canadian Journal of Soil Science 76: 395-401.

Charpentier, H., Doumbia, S., Coulibaly, Z. and Zana, O. 1999. Stabilizing agriculture in northern and central Cote d'Ivoire: what are the new farming systems? Agriculture-et-Developpement 21: 4-70.

Chapman, H.D. 1965. Cation exchange capacity in methods of soil analysis. Part 2. Agronomy Monograph 9: 891-894.

CIMMYT. 1998. From agronomic data to farmer recommendations. An Economics Training Manual. Completely Revised Edition. CIMMYT, Mexico, D.F., Mexico. pp.79.

Copeland, P.J. and Crookston, R. K. 1992. Crop sequence affects nutrient composition of corn and soybean grown under high fertility. Agronomy Journal 84: 503 509.

Dewis, J. and Freitas, F. 1984. Physical and chemical methods of soil and water analysis. FAO Soil Bulletin No. 10. FAO, Rome. pp. 275.

FAO (Food and Agricultural Organization). 1990. Guideline for soil description. Rome, Italy. pp.193.

Freed, M., Eisensmith, S., Goetz, S., Reicosky, D., Smail, V. and Wolberg, P. 1989. User's Guide to Mstat-C: A Software Program for the design, management, and analysis of agronomic research experiments. Michigan State University. East Lansing. U.S.A.

Habtamu, A., Reddy, M.S., Teshale A. and Jibril, M. 1996. Maize based cropping systems for sustainable Agriculture in Semi-arid areas of Ethiopia. In: Woldeyesus, S., Zerihun, T. and Nugussie, A. (eds.). Increasing Food Production Through Improved Crop Management. Proceedings of the First and Inaugural Conference of Agronomy and Crop Physiology Society of Ethiopia. Addis Ababa, Ethiopia. pp. 74 82.

Halvorson, A.D., Black, A.L., Krupinsky, J.M., Merrill, S.D., Wienhold, B.J. and Tanaka, D.L. 2000. Spring wheat response to tillage and nitrogen fertilization in rotation with sunflower and winter wheat. Agronomy Journal 92: 136- 144.

Henao, J. and Baanante, C.A. 1999. An evaluation strategies to use indigenous and imported sources of phosphorous to improve soil fertility and land productivity in Mali. International Fertilizer 
Development Center (IFDC), Muscle Shoals, Alabama, U.S.A. pp.55.

Higgs, R.L., Peterson, A.F. and Paulsen, W.H., 1990. Crop rotation: Sustainable and profitable. Journal of Soil and Water Conservation 45: 68 - 70.

Holford, I.C.R. and Crocker, G.J. 1997. A comparison of chickpeas and pasture legumes for sustaining yields and nitrogen status of subsequent wheat. Australian Journal of Agricultural Research 48: 305-315.

Jackson, M.L. 1958. Soil Chemical Analysis. Prentice Hall, Inc., Engle Wood Cliffs. New Jersey. pp. 183-204.

Kapkiyai, J. 1996. Dynamics of soil organic carbon, nitrogen and microbial biomass in a long-term experiment as affected by inorganic and organic fertilization. M. Sc. Thesis, University of Nairobi. pp.102.

Kumar, V.D.K., Dart, P.J. and Sastry, P.V.S.S. 1983. Residual effect of pigeon pea (Cajanus cajan) on yield and nitrogen response of maize. Experimental Agriculture 19: 131-141.

Landon, J R. 1991. Booker Tropical Soil Manual: A Handbook for Soil Survey and Agricultural Land Evaluation in the Tropics and Subtropics. Longman Scientific and Technical, Essex, New York. pp.474.

McLean, E.O. 1965. Aluminum. In: Black, C.A. (eds.). Methods of soil analysis. American Society of Agronomy, Madison, Wisconsin, U.S.A., Agronomy 9: 978-998.

NMSA (National Meteorological Service Agency). 2003. Meteorological data of Bako area for 1961-2003. Addis Ababa, Ethiopia.

Nugusse, T. M. 1995. Cropping System Research Status and Future Trends in the Rift Valley: II. Weed Insects pests and Diseases. In: Habtu, A. (eds.). Proceedings of the $25^{\text {th }}$ Anniversary of Nazareth Agricultural Research Center. Nazareth, Ethiopia. pp. $98-105$.

Olsen, S.R., Cole. C.V., Watanabe, F.S. and Dean, L.A. 1954. Estimation of available phosphorus in soils by extraction with sodium bicarbonate. USDA Circular 939: 1-19.

Patwary, S.U., Haque, Q. and Badruddin, M. 1989. Role of legume on nitrogen balance and a value of soil under different sequential cropping systems. Thailand Journal of Agricultural Science 22: 213 - 221.

Ramteke, J.R., Sinha, M.N. and Rai, R.K. 1986. Productivity and economic analysis of multiple cropping systems. Journal of Research Haryana Agricultural University 16: 361 -366.

Rao, M.R. and Mathuva, M.N. 2000. Legumes for improving maize yields and income in semi-arid Kenya. Agricultural Economics and Environment 78: 123 137.

Riedell, W.E., Schumacher, T.E., Clay, S.A., Ellsbury, M.M., Pravecek, M. and Evenson, P.D. 1998. Corn and soil fertility response to crop rotation with low, medium or high inputs. Crop Science 38: 427 - 433.

Reddy, M.S., Nigussie T.M. and Chanyalew T. 1994. Developing improved cropping systems for dry land areas of Ethiopia. In: Reddy, M.S. and Kidane, G. (eds.). Developing of Technologies for the Dry Land Farming Areas of Ethiopia. Proceedings for the First National Workshop on dry land Farming Research in
Ethiopia. Institute of Agricultural Research (IAR) and Food and Agricultural Organization (FAO), Addis Ababa, Ethiopia. pp. 116 - 129.

Sayre, K. D. 1999. Ensuring the use of sustainable crop management strategies by small-scale wheat farmers in the 21st century. In: The Tenth Regional Wheat Workshop for Eastern, Central and Southern Africa. Addis Ababa, Ethiopia, CIMMYT. pp. 119 - 141.

Shepherd, M.A. and Sylvester-Bradley, R. 1996. Effect of nitrogen fertilizer applied to winter oilseed rape (Brassica napus) on soil mineral nitrogen after harvest and on the response of a succeeding crop of winter wheat to nitrogen fertilizer. Journal of Agricultural Science 126: 63-74.

Singh, R.D., Gupta, R.K., Beniwal, R.K. and Rai, R.N. 1987. Production potential of rice-wheat and maizewheat cropping systems under different levels of fertilizer. Indian Journal of Agricultural Science 57: 325 329.

Soper, R.J. and Grenier, M.R. 1987. Fertility value of annual legume in crop rotation. In: Manitoba Agronomy Forum-Winnipeg. Manitoba Institute of Agrologists, Winnipeg. pp. 7-12.

Tadesse, Y. and Tolessa, D. 1998. Cultural practices, cropping systems and fertility studies on maize production in eastern, western Wallaga and Assosa. In: Beyene, S. and Aberra, D. (eds.). Agricultural Research and Technology Transfer Attempts and Achievement in Western Ethiopia. Proceedings of the Third Technology Generation, Transfer and Gap Analysis Workshop. Nekemt, Ethiopia. pp. 133-139.

Van Reeuwijk, L.P. 1992. Procedures for Soil Analysis. 3 ${ }^{\text {rd }}$ edition. International Soil Reference and Information Center Wageningen (ISRIC). The Netherlands, Wageningen.

Wakene, N. 2001. Assessment of important physicochemical properties of dystric udalf (dystric Nitosols) under different management system in Bako area, Western Ethiopia. M.Sc.thesis, Alemaya University, Ethiopia.

Wakene, N., Tolera, A., Friesen, D.K., Abdenna, D. and Berhanu, D. 2001. Evaluation of compost for maize production under farmers' conditions. In: Friesen, D.K. and Palmer, A.F.E. (eds.). Integrated Approaches to Higher Maize Productivity in New Millennium. Proceedings of the Seventh Eastern and Southern Regional Maize Conference, CIMMYT and KARI, Nairobi, Kenya. pp. 382 - 386.

Walkley, A. and Black, C.A. 1934. An examination of Degtjareff method for determining soil organic matter and a proposed modification of the chronic acid titration method. Soil Science 37: 29-38

Wu, T.Y., Schoenau, J.J., Li, F.M., Qian, P.Y., malhi, S.S. and Shi, Y.C. 2003. Effect of tillage and rotation on organic carbon forms in chernozemic soils in Saskatchewan. Journal Plant Nutrition Soil Science 166: 385 $-393$.

Zentner, R.P., Campbell, C.A., Biederbeck, V.O., Miller, P.D., Selles, F. and Fernandez, M.R. 2001. In search of a sustainable cropping system for the semiarid Canadian Prairies. Journal Sustainable Agriculture 18: 117136. 